\title{
Risk, Issues In Promotion Of Brands Through Celebrity Endorsement Strategy
}

\author{
Pavan Patil ${ }^{1}$ \\ ${ }^{1}$ Assistant Professor, Marketing Management, Government Of Maharashtra's Sydenham \\ Institute of Management Studies, Research and Entrepreneurship Education (SIMSREE), \\ Churchgate, Mumbai, Maharashtra 400020, India
}

\begin{abstract}
The usage of celebrity endorsement strategy for promoting products and services has increased dramatically in the recent time. In fast changing world, customers avoid to notice advertisements while going through the newspapers or watching television programs. But in such an environment also, the glamour and aura of a celebrity seldom goes unnoticed. As the acceptance of promotion of products and services by marketers through celebrity endorsement is rising, it's interesting to study and focus on issues arising with this practice. There are incidents occurred where celebrity endorser, ambassador got in scandal or embarrassing state unanticipated incident, which could result in risky environment for endorsed brand, and marketer. The paper tries to draw attention towards risk and issues in promotion of brands by celebrity endorsement; and identify such incidents. The study is exploratory in nature and selected cases are used for analysis. The paper throws light on the importance of considering the risk, issues in decision making of promotion of brands by celebrity endorsers, ambassadors and concludes that there are issues and risk in promotion of brands by celebrity endorsement strategy.
\end{abstract}

Keywords: Ambassador, Celebrity, Endorser, Endorsement, Issues, Risks

\section{Introduction}

Celebrity is one who is famous in his or her field of representation and attracts attention among the people. He/ she may be an actor, sports star, business tycoon, politician, etc. Becoming and being a celebrity is not easy, it calls for sustained and disciplined efforts to excel in the chosen field. When the status is achieved, leveraging that fame and name exterior to the profession, however, comes effortlessly. Media coverage spreads recognition beyond the domain of professional expertise and also practitioners are ever eager to get a celebrity to associate with brands. A commercial quantified value gets linked with the celebrity's face that promises widespread appeal and recognition. The magnetic and famous appeal, instant awareness and familiarity of the celebrity assist marketers to grab and keep the attention of their intended customer segment. Celebrity endorsement is form of brand or advertising campaign that involves a well-known person using their fame to promote a product or service. Marketers are willing to allocate promotional expense to get celebrities as spokespeople, as celebrities bring quick attention to the products they endorse. Sometimes this attention can be positive whereas sometimes it can be negative also. The saying "any publicity is good publicity" is commonly applicable to celebrities and brands alike, and it makes an interesting argument as: why paying celebrities to endorse brands is money invested or risked? If an attachment with a celebrity leads to more damage than good in consumer's perception of the brand and at times celebrity's negative incidents can be transferred on to the brand he or she is endorsing. One of the most risky thing is: since the brand rides on the 'image' portrayed by the celebrity, if that individual is caught in an embarrassing situation/issue or unanticipated incident in his/her personal or professional life, the brand stands vulnerable to be part of the risk.

\section{Objectives:}

2.1 To identify incidents where celebrity endorser, ambassador caught in scandal or embarrassing situation or unanticipated incident.

2.2 To study risk and issues in promotion of brands through celebrity endorsement strategy.

\section{Purpose of Research:}

The purpose of research is to identify issues, incidents, risks in promotion of products and services through celebrity endorsement strategy as this can be considered while taking the decision related to promotion of brands through celebrity endorsement 
strategy as any negative incident with celebrity endorser can affect the endorsed brand and company.

\section{Literature Review}

Mazzini M. et al (2017) concluded that the biggest risk in celebrity endorsement is celebrity getting entangled in negative publicity and states that negative information has a stronger impact over positive information and also concluded that as positive attributes might transfer to the brand, in a way negative attributes also may spill over to the endorsed brand, probably in higher magnitude ${ }^{[13]}$. Erdogen Z., Drollinger T. (2008) stated in implications that the risks of celebrity endorsement concerning negative consequences are formidable and should be considered and even secured against by a death and disgrace policy ${ }^{[6]}$. Till B., Shimp T. (1998) stated in implications that advertiser has no control over the celebrity's future behaviour and any negative information about a celebrity endorser may lead to reduction in the celebrity's allure, and therefore the appeal of the brand the celebrity has endorsed ${ }^{[25]}$. Sisodia D, More A. (2010) concluded that all the celebrity glitter is not gold, but it may be and also opined that celebrity endorsement strategy can bring out the expected output with right use and could be evidenced as a disaster if unintelligently blended ${ }^{[23]}$. Varalakshmi T. (2013) concluded that the severity resulting because of unethical behaviors of celebrities can vary and it is required from practitioners and celebrities to study all the ethical considerations prior endorsement ${ }^{[27]}$. Miller F., Laczniak G. (2011) concluded that utilizing an athlete endorser for promotion can lead to unanticipated negative effects for endorsed brand because of unpredictable nature of their behavior apart from field ${ }^{[14]}$. Francois A. C. et al (2013) concluded that when the reputation of the endorser is affected by misconduct, the brand may also come under risk. Should it continue or cancel the endorsement association with the celebrity depend on extent of interconnection between celerity and brand in consumers' minds with respect to shared meaning ${ }^{[8]}$. (People generally weigh -ve news more heavily than +ve news when forming an overall evaluation of a target (Klein, 1996; Mizerski, 1982; Skowronski \& Carlston, 1989). Consequently, -ve publicity could have a devastating effect. As per the Merriam formula calculation -ve news impact results four times more than +ve news (Kroloff, 1988). It could be because -ve news is high in attention catching (Fiske, 1980). Brand usually has implications of -ve news. When negative information is of celebrity endorser of a brand, its impact on brand evaluations is largely determined by perceptions of the endorser's blameworthiness
ISSN 2455-6378

(Louie, Kulik, \& Jacobson, 2001; Louie \& Obermiller, 2002) ${ }^{[4]}$.

\section{Risks / disadvantages in promotion of products and services through celebrity endorsement strategy ${ }^{[11]}$. \\ 5.1 Celebrity overshadowing the endorsed} brand: There is a possibility that the celebrity is remembered more by consumers than a brand.

5.2 Compulsory Evil: Marketers have felt that once the brand is linked with the celebrity it becomes hard to promote it without them.

5.3 Celebrity credibility: In the present scenario brand endorsement has to face knowledgeable customer who has begun to understand about endorsement of a brand. The celebrity is said to fool the customer as he is paid for the endorsement.

5.4 Image Match-up: A difference in the image of the celebrity and the brand can lead to serious damages to both sides. Unless there is congruence between celebrities' own image and that of brand the strategy of endorsement won't be much fruitful.

5.5 Multiple Endorsements: The multiple endorsements of brands have led to celebrity clutter. Celebrities endorsing multiple brands have confused the customer and resulted to dilution in the celebrities' worth.

5.6 Influence of Celebrity scandals and moral violation: A number of celebrities have been involved in such issues that could embarrass the marketer whose brand they have endorsed.

\section{Analysis of Celebrity caught in scandal or embarrassing situation or unanticipated incident resulting in risks and issues.}

\author{
6.1 Celebrity-Yuvraj Singh - Brand -Revital, \\ Company- Ranbaxy
}

Well known cricketer from Indian cricket team Yuvraj Singh the first brand ambassador for Revital, a flagship OTC brand of Ranbaxy, diagnosed and treated for cancer ${ }^{[12]}$.

\subsection{Celebrity -Sanjay Dutt - Brand /Company - Gitanjali Group}

Sanjay Dutt, endorser of products from Gtanjali Group, included Sangini diamond jewellery and Rotary watches. Supreme Court sent Dutt in Jail for five years. Supreme court of India's decision of Sanjay Dutt's conviction under Arms Act ${ }^{[9,15,26]}$. 
6.3 Celebrity- Jia Khan - Brand/ CompanyWrangler

Wrangler, a part of VF Corporation, was brought in India by Arvind Brands. Wrangler launched a new range of denim wear for girls. Actress Jia Khan an ambassador for female range of products for the brand was found hanging from a ceiling fan and she is no more ${ }^{[2,7,10]}$.

6.4 Celebrity- Lisa Ray - Brand/ Company- Rado

Lisa Ray ambassador for Rado was detected and treated with multiple Myeloma, a cancer of the white blood cells that produce antibodies ${ }^{[3,20]}$.

\subsection{Celebrity- Irfan Khan - Brand /Company -} Syska Led

Irfan Khan an ambassador for Syska Led diagnosed and treated for neuroendocrine tumour, an infrequent form of cancer ${ }^{[19,28]}$.

6.6 Celebrity- Sonali Bendre- Brand /CompanySunny Cooking Oil, IFFCO

Sonali Bendre an ambassador for brand Sunny Cooking Oil of the company IFFCO detected and treated for metastatic cancer ${ }^{[1,17,22]}$.

6.7 Celebrity- Salman Khan - Brand/ CompanyBahamas Relaxo footwear

Cases filed under Arms Act and Wildlife Protection Act on Salman Khan an ambassador for brand Bahamas Relaxo footwear ${ }^{[18,21]}$

6.8 Celebrity-S. Sreesanth - Brand/ CompanyMuthoot Group

S. Sreesanth a bowler from Indian cricket team the brand ambassador for Muthoot Group, banned by Board of control for cricket in India (BCCI) for IPL spot- fixing ${ }^{[5,16,24]}$.

It can be analyzed that celebrity endorsers, ambassadors in their lives may face any uncertain negative incident or issue as identified with above mentioned celebrities. The endorsement contract and brand can adversely get affected or come to an end depending on the magnitude of the negative incident. The effect of negative celebrity information is greater when the associative link between the brand and celebrity is strong ${ }^{[25]}$. Considering the duration and involvement of endorsement, brand ambassador endorses brand longer than endorser which may lead to stronger link between brand ambassador and brand than endorser and brand which could lead to higher risk of negative information about brand ambassador than brand endorser on the concerned brand. Along with and apart from influence of celebrity scandals and moral violation risks or disadvantages mentioned in the study, unanticipated, unintended issues and incidents are observed as the celebrity endorsers, ambassadors considered in the study have faced incidents like death, disease and legal action. This arises risk to endorsed brand concerning implications and future prospects.

\section{Methodology:}

The study is an attempt of exploratory, conceptual in nature and direction. Information is collected through search on internet, websites, e-papers, journals. Secondary data is collected and analysed qualitatively in the study. The study focuses on conveniently selected eight cases where celebrity endorser, ambassador caught in scandal or embarrassing situation or unanticipated incident.

\section{Findings:}

The celebrity endorser's, ambassadors cases considered in study namely Yuvraj Singh, Lisa Ray, Irfan Khan, and Sonali Bendre are identified with detection of Cancer, Jia Khan lost her life and Sanjay Dutt, Salman Khan, and S. Sreesanth came under purview of legal matters.

\section{Limitations:}

The study is done for conveniently selected cases of celebrities as endorser, ambassadors and their single brand endorsement is considered as an example. The cases have legal dimension concerning court judgment and investigation. The study is exploratory in nature and not a conclusive one. The study did not focus on impact of incident related to celebrity on brand, company or customer.

\section{Further research areas:}

The further study can be done for impact of negative incident or issue on part of endorser, ambassador on brand, company, celebrity and customer.

\section{Implication:}

The implication of the study is in the decision making related to promotion of brands by celebrity endorsement strategy for marketers concerning selecting celebrity endorsers and planning endorsement contract.

\section{Conclusions}

There is a risk in promoting brands through celebrity endorsement strategy as risk and issue arises concerning the implications and future of the brand endorsement related to any of the following, behavior of celebrity endorser in public, breaking of law, any natural unanticipated happening, any 
negative happening in personal life, accident, death, disease. There is a potential and possibility in celebrity for involvement in unwanted, unanticipated circumstances, situations whose repercussions can transfer further on brand and company they are endorsing. Unanticipated, unintended incidents, happenings in personal and professional life of celebrities could be said, added and considered as one of the important risks in promoting brands through celebrity endorsement strategy along with previously studied and mentioned risks. Considering the possibility of stronger associative link, extent of interaction between brand and celebrity which may be due to longer endorsement duration and involvement of brand ambassadors than endorsers, the effect of negative celebrity information as ambassadors could be greater on the concerned brand as compared to endorser. So while taking the decision related to promotion of brands by celebrity endorsement strategy, decision maker need to consider these issues, risk and incidents while selecting endorsers, ambassadors and planning endorsement contract.

\section{Acknowledgments}

I kindly acknowledge Dr. P.W.Kale, for his valuable input and guidance for this study.

\section{References}

[1]. AdAgeIndiaBureau. (2016, Septmber 23). Advertising. Retrieved from http://www.adageindia.in: http://www.adageindia.in/advertising/sunny -oils-presses-plagiarism-charges-againstaashirvaad-multigrain-atta-withasci/articleshow/54472430.cms

[2]. Agencyfaqs. (2007, November 01). News/story. Retrieved from http://www.afaqs.com: http://www.afaqs.com/news/story/19555_W rangler-appoints-Jia-Khan-as-brandambassador-for-its-womens-range

[3]. Banerji, O. (2012, July 16). www.indiatoday.in. Retrieved from https://www.indiatoday.in/magazine/supple ment/story/20120716-lisa-ray-afreenkasoor-water-bollywood-hollywood-deepamehta-758982-2012-07-06

[4]. Candy PSFong, R. (2012). Consumers' Reactions to a Celebrity. Psychology and Marketing, Vol. 29(11), 885-896.

[5]. Economictimes.indiatimes.com. (n.d.). Retrieved from https://economictimes.indiatimes.com/news /sports/decide-appeal-against-sreesanthsdischarge-in-ipl-spot-fixing-sc-to-delhihc/articleshow/64175142.cms
[6]. Erdogan B. Z., Drollinger T., (2008), "Death and Disgrace Insurance for Celebrity Endorsers: A Luxury or Necessity?", Journal of Current Issues and Research in Advertising, Volume 30, Number 1, Spring 2008, Page No.71-78.

[7]. Express News Service. (2015, May 14). Retrieved from indianexpress.com: http://indianexpress.com/article/entertainme nt/bollywood/jiah-khan-death-cbi-searchesresidence-of-aditya-pancholi/

[8]. Francois A. Carrilat, A. D. (2013, March). For Better or Worse? What to do when celebrity endorsements go bad. Journal of Advertising Research, 15-30.

[9]. Ghosal, S. (2013, April 08). Retrieved from www.economictimes.indiatimes.com: https://economictimes.indiatimes.com/indus try/services/advertising/despite-jail-termgitanjali-to-continue-featuring-sanjay-duttin-its-ads/articleshow/19435751.cms

[10]. http://www.thehindubusinessline.com. (n.d.). Retrieved from http://www.thehindubusinessline.com/today s-paper/tp-marketing/arvind-unveilswrangler-girl/article 1673872.ece

[11]. Khatri P., (2006), “Celebrity Endorsement: A Strategic Promotion Perspective", Indian Media Studies Journal, Vol.1, No.1. JulyDec 2006.

[12]. Mathew, J. C. (2013, JANUARY 20). Article/ Revital get a booster dose. Retrieved from https://www.businessstandard.com: https://www.businessstandard.com/article/management/revitalgets-a-booster-dose-112032800111_1.html

[13]. Mazzini Muda, R. M. (2017). Celebrity Endorsement in Advertising: A doubleedged sword. Journal of ASIAN Behavioural Studies, 21-32.

[14]. Miller F, L. G. (2011, September). The Ethics of Celebrity- Athlete Endorsement What happens when a Star steps out of Bounds? Journal of Advertising Research, 499-510.

[15]. Pinto, V. S. (2013, March 21). Article /current-affairs. Retrieved from http://www.business-standard.com: http://www.businessstandard.com/article/current-affairs/sanjaydutt-verdict-impending-brandendorsements-may-take-a-hit113032100208_1.html

[16]. Ray, S. G. (2013, February 05). Retrieved from www.business-standard.com: https://www.businessstandard.com/article/companies/sreesanthbowls-over-sponsors-107092501097_1.html

[17]. Retrieved from http://www.iffco.com: http://www.iffco.com/sunny.aspx 
[18]. Retrieved

from http://www.relaxofootwear.com: http://www.relaxofootwear.com/bahamas/D efault.aspx\#home

[19]. Retrieved from https://syska.co.in/led: https://syska.co.in/led

[20]. Retrieved from https://www.rado.com: https://www.rado.com/about/ambassadors

[21]. Retrieved from timesofindia.indiatimes.com/: https://timesofindia.indiatimes.com/india/sa lman-khan-and-all-cases-against-him-10points/listshow/56638949.cms

[22]. Retrieved from www.indiatoday.in: https://www.ndtv.com/health/sonalibendres-metastatic-cancer-causestreatment-and-diagnosis-1878323

[23]. Sisodia S., More A.V., (2010), "Celebrity Communication In Brand Promotions: A Risk And Reward Analysis", Indian Journal of Commerce \& Management Studies, ISSN - 2229-5674, Vol.-I, Issue 1, November 2010, Page No. 61-66.

[24]. Sudhir. (2013, May 19). Retrieved from www.firstpost.com:

https://www.firstpost.com/sports/ipl/underst anding-sreesanth-why-he-may-have-givenin-to-temptation-796103.html

[25]. Till B.D. and Shimp T.A., (1998), "Endorsers in Advertising: The Case of Negative Celebrity Information", the Journal of Advertising, Volume XXVII, Number 1, spring 1998, Page No. 67-84.

[26]. Tiwari, N. (2011, August 06). Retrieved from timesofindia.indiatimes.com: https://timesofindia.indiatimes.com/entertai nment/hindi/bollywood/news/SanjayManyata-Dutt-to-endorse-a-jewellerybrand/articleshow/9504883.cms

[27]. Varalakshmi T., (2013), "Is Celebrity Endorsement Ethical or Unethical in Brand Building”, Indian Journal of Applied Research, Vol.3, Issue 12, December 2013, Page No. 288-291.

[28]. www.hindustantimes.com. (n.d.). Retrieved from https://www.hindustantimes.com/bollywood /after-cancer-jolt-and-four-rounds-ofchemo-clarity-has-come-as-a-lightningsays-irrfan-khan/storyyPJsFvbCeBCJjrG0SnPBNN.html 